\title{
Ethnocentrism in Edward Zwick's The Last Samurai Movie: Postcolonial Perspective
}

\author{
Yogi Setyo Pradana \\ Ali Mustofa \\ English Literature, Faculty of Languages and Arts \\ Universitas Negeri Surabaya, \\ Jl. Lidah Wetan, Lakasantri, Surabaya \\ alimustofa@,unesa.ac.id
}

Article History: Submitted on $27^{\text {th }}$ Mei 2021; Accepted on $12^{\text {th }}$ November 2021;

Published on 30 $0^{\text {th }}$ December 2021

\begin{abstract}
The research focused on ethnocentrism in Edward Zwick's The Last Samurai movie. It was intended to identify how ethnocentrism is depicted and reflected in the life of samurai. Ethnocentrism comprises values, feelings, and behaviors which are reflected in individuals or people's thoughts and perceptions. Ethnocentrism is a set of beliefs that compromises one's ethnic community or society is superior to that of other ethnic groups or cultures. The ethnocentrism theory, originally developed by Sumner (1906), was used to analyze the issues in the movie. The data were obtained by watching the film, reading the movie's script, identifying the data based on the topic of study, and categorizing the data to contrast and highlight the issues of ethnocentrism in the movie. The result of the analysis showed that ethnocentrism was presented in the form of characters' actions and statements. These actions have been adopted into the spirit of samurai warriors to protect their group culture to fight against Japanese emperor army troops. The analysis shows that there are three aspects of ethnocentrism revealed in the movie: firstly, loyal to in-group norms; secondly, express ingroup pride; and thirdly, judge and underestimate the out-group. These three features of ethnocentrism are then being internalized and perceived by samurai physically, psychologically, and ideologically which then influenced their way of life.
\end{abstract}

Keywords: ethnocentrism; postcolonialism; Samurai; loyal; pride; prejudice; othering 


\section{INTRODUCTION}

Ethnocentrism is understood as someone's belief that one's group is the core of everything and the perception is important for a particular group of culture. Ethnocentrism is an attitudinal construct that focuses on the belief, and that, as an attitude, it also has strong emotional and behavioral aspects (Sumner, 1906; Aldrich \& Kasuku, 2012; Etinson, 2018). It is profoundly embedded in the human condition and is most commonly presented in all racial groups, albeit to varying degrees. Ethnocentrism is a mindset that includes values, feelings, and behaviors. Ethnocentrism has been with humanity since prehistoric societies, and it was still recognized by ancient philosophers. However, it was only in the second quarter of the twentieth century that the term became incorporated into the social sciences. Since then, social scientists and a vast range of other academics have embraced the term (Hammond \& Axelrod, 2006).

Racism, prejudice, mental closure, and an oppressive personality system are also linked to ethnocentrism. It is commonly used in social and political science because it demonstrates a strong and readily recognizable mindset that can be measured legally. While ethnocentrism is linked to racism, it distinguishes it from racial prejudice in that it does not include a hostile attitude toward other cultures or races (Permatasari et al., 2019). According to Sumner, the view of certain group cultures can be known as vital things, while other group cultures are reduced to the lower status in society.

Therefore, culture is concerned with many different objects, both biological and physiological, as comportment, music, traditions, and so on. As it affects several facets of life, it is seen in many different activities. Matsumoto describes culture because a group of people, though completely different from each individual, share their attitudes, ideals, convictions, and conduct from one generation through the next generation (Matsumoto, 2002). Community is dealt with in reality through specific individuals or cultures. It reveals a somewhat different personality including its collective consciousness. There are many communities in the society with their cultural specialty including people in ceremony, conduct, faith, and attitude.

Ethnocentrism encourages in-group preferences in terms of interaction and solidarity, as well as outsider-group animosity. If one group does not tolerate the other, the people within this group assume that their group is preferable to the other (Hooghe, 2008). Ethnocentrism is the belief that one's ethnic community or society is superior to that of other ethnic groups or cultures. Dealing with that, one's cultural traditions should be extended fairly to other ethnic groups or societies. Ethnocentrism also believes that their philosophy, action, or mindset is the greatest thing in any way, even the most essential, right, and beautiful and that all cultures are inferior. People with this mindset are referred to as ethnocentric. Referring to that, those ethnocentric groups 
will judge the different communities from which they process knowledge if they are ethnocentric and intolerant. As a consequence, people believe that those who live their lives differently are immoral, unnatural, or in the wrong position.

Edward Zwick, the director of The Last Samurai movie, is well-known for his passion throughout managing but also his experience as a producer on television shows and films in the industry. He was born in Chicago in 1952. Zwick began his career as a journalist at Rolling Stone after graduating from the AFI Conservatory in Los Angeles. He advanced his career and found work as a film producer, editor, and director in the television industry. The one discussed in this study, The Last Samurai movie, received four different Oscar nominations such as acting category, art direction, sound, and costume.

The Last Samurai movie discusses American military officers who train Japanese soldiers how to fight and to battle against the samurai. Samurai is a legacy from their ancestors that has an important role in Japanese society. They have a preference that samurai culture is better than other cultures. Ethnocentrism is the main theme of The Last Samurai (Hooghe, 2008). Hooghe argues that social individuality approaches believe that ethnocentrism is the output of strong recognition toward in-group of someone, which directly leads to negative sense toward other culture and underestimate of particular out-group members. From the above arguments, the present paper discussed 1). How is the idea of ethnocentrism depicted in the movie The Last Samurai? 2). How does the movie represent the oppositional binaries between east and west in which the stereotypes are portrayed as the hierarchical boundaries and burdens toward each other's characters' feelings and perceptions?

Furthermore, the research problem about ethnocentrism analyzes the standpoint that related to Japanese culture and western culture. In this sense, the dichotomy of East and West is contested. The Last Samurai movie tells the story of an American soldier and samurai warrior who are experiencing being ethnocentric to their own culture. At the beginning of the story, Nathan Algren is known as US military officer employed to train the country's first new army by the Japanese Emperor. When the government tries to destroy the traditional samurai warrior class to implement more westernized tradition for some reasons of commercial-friendly policies, it fails miserably. He is suddenly enchanted by his experiences with the life of samurai, which then puts him in the middle of a fight between two ages and two continents.

In the ring spectrum, Algren puts a recruit to the test. Algren thinks they are not prepared to fight against the samurai, so he goes up to one of the targets and warns a soldier that if he does not kill Algren, Algren will kill him. The soldier is terrified and the scene shows that Algren wants to kill a samurai warrior by preparing the Japanese army. By this, he becomes ethnocentric to Japanese culture because of the uniqueness of its culture and to be a part of the samurai until the end of the movie. He identifies himself to be a part of 
and to help samurai warriors to go to the war. He shows how well he had learned from his enemy of the ways of the samurai's way of life.

The Last Samurai movie has previously been discussed by many scholars (Grajdian, 2020). Maria Grajdian investigates the movie by reframing masculinity in the character embodied by Tom Cruise, a typical white male from a Japanese perspective. The research showed an unexpectedly refreshing insight into the prevalent masculinity ideal in Japan as subliminally suggested by the Japanese characters. Meanwhile, Ingvason investigates the way of the warrior in modern Japan. The samurai is the Japanese version of a warrior who serves their lords with faith and loyalty, ready to give all their lives in the service of their lord (Ingvason, 2017). Ingvason claims that Japan's modernization pushed out the samurai and replaced them with new warfare. Concerning the above previous studies, the present paper investigates how ethnocentrism is depicted and reflected in the samurai s life in The Last Samurai movie. It also approves that Japanese masculinity has been long preserved and maintained within their culture to represent their toughness, strong, power, and integrity, as in opposition to what have been argued and narrated by western culture that easterners are weak, docile, submissive, feminine, and impotent.

\section{METHOD}

This research followed several stages which determine the characteristics of being ethnocentric as have been promoted by Sumner (1906) and then developed by other sociologists such as Bizumic \& Duckitt (2008); Etinson (2018); Hammond \& Axelrod (2006); Hooghe (2008); and Keith (2015). Ethnocentrism is a part of postcolonial issues which centers on the feelings and attitudes of inclusive behavior. Therefore, this research applied the postcolonial reading method. Postcolonial reading evaluated the binaries and dichotomies in the text. The binaries were discussed to confront the senses of colonialism which involve the geographical poles of east and west in the mode of opposition. The dichotomies were put in a set of power relations that showed incompatible goals of domination.

To collect the data, The Last Samurai movie was firstly enjoyed and analyzed to understand its contents and dialogue. Secondly, the script of the movie was also read to gain some more insights on the narration and the explanation from the scriptwriter and also the cast. Thirdly, the elements of cinematographic study such as mise en scene, costume, setting, shots, camera angles, and lightings were also analyzed and discussed. Fourthly, selected data were analyzed, categorized, and discussed by using Sumner's critical lenses of ethnocentrism which encompassed the three components of ethnocentrism: loyal to in-group norms, expressing in-group pride, and underestimating outgroup.

\section{FINDINGS AND DISCUSSION}

The Last Samurai is a story about a party of samurai in a deep mountain village. The main male character is Katsumoto, a samurai warrior chief who is tasked to defend the samurai colony. His colony is proud of its samurai warriors, and they occasionally ban people from other countries to enter the colony. It can be seen in 
a variety of settings, including the home, culture, and how people treat their culture. Samurai are distinguished by their two swords, long and short ones. They are referred to as "katana" and "wakizaki" respectively. They normally remain in their lords' castles and are also part of a military aristocracy household. The analysis found out that being ethnocentric, the samurai show some characteristics as the following:

\section{Loyal to in-group norms}

Ethnocentric people will perform loyalty. It is embodied by a commitment to in-group rules and honesty throughout relations towards fellow in-group members. Samurai had a unique routine that they practice every day. They practice imitating any kind of traditional teaching their ancestors had in the past without questioning it (Ingvason, 2017). They also learn it by doing and practicing it every day to make it more internalized. The structured ritual of "seppuk.u" seems to have been a death ceremony, and this is the most terrible yet honorific, in which samurai must disembowel them rather than commit suicide [hara-kiri]. It was often used by samurai who would rather die than face humiliation after defeat or the humiliation of imprisonment or torture at the hands of their opponents. Samurai would also do seppuku if they had defeated their lords, depending on the nature of their shortcomings, because samurai valued honor, strength, discipline, and devotion to their lord. The act of seppuku was a way for them to demonstrate their will, as well as to keep their honor and pride intact. Hara-kiri and seppuku share the same meaning in Japan, but seppuku is more often used because the Japanese synonym for seppuku is more prestigious.

The first seppuku was mentioned sometime in the 12th century, but it became more common after a while because samurai believed that this was an honorable way to die to atone for their mistakes. If a samurai was ever sentenced to death, they had the option of committing seppuku rather than being disgraced by being executed by a commoner, so that their honor and pride would be preserved following their death. The quotes that reflect adherence to in-group standards are mentioned below.

Picture 1:

Katsumoto cuts the head of General Hasegawa

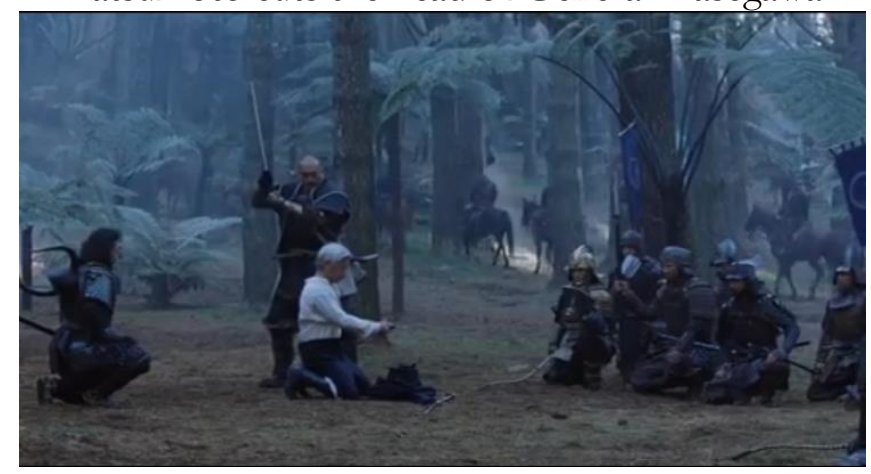

"Nathan: I've seen what you do to your enemies."

"Katsumoto: Warriors in your country do not kill?"

"Nathan: They don't cut the heads off defeated, kneeling men."

"Katsumoto: "General Hasegawa asked me to help him end his life. A Samurai cannot stand the shame of defeat. I was honored to cut off his head." (Logan, 2003)

In the quotation above, Katsumoto claims that samurai may not bear the defeat embarrassment. As a samurai warrior, he thinks it is a pleasure to shave General Hasegawa's head. Sumner claims that his society is equivalent to that of out-groups 
and that the latter is barbaric. His concept of ethnocentrism includes not only the advancement of one's race but also the development of discriminatory attitudes toward others. In the movie, Katsumoto lets Nathan alive to stay in his village. He lets him live to learn about his enemy which is Nathan, who has a different culture. Nathan is curious to know why Katsumoto let him live and stay in his village and does not kill him as he did toward general Hasegawa.

Furthermore, Katsumoto practices the samurai custom of only dying with his sword, as portrayed by him. "I will die by the sword," he declares. "It's all mine." He needs to die with dignity because he believes that if a samurai is humiliated by failure, he will kill himself with his sword rather than by an enemy's weapon (Hooghe, 2008). Hoogart and Williams argue that they were interested in culture as the 'texture of lived experience' or a 'structure of feeling' rather than as a body of intellectual and artistic activities separate from the rest of society.

The last scene shows Nathan's loyalty to the samurai. Adherence to ingroup rules including trustworthiness throughout interactions with fellow in-group members are examples of loyalty. At the end of the war, he gives Katsumoto a sword to Japan emperor to remind him about the struggle of samurai (Hagakure: The Book of the Samurai - Yamamoto Tsunetomo - Google Books, n.d.). Yamamoto argues that the way samurai is found in death when it comes with the choice. It is not particularly difficult. There will be always a quick choice of death; found in death without achieving one's goal; a dog's death does seem to be a wasteful way of sophisticates.

The development and strength of a behavioral propensity to partiality amongst people with the little cognitive capacity and limited reasoning is also a part of samurais attitudes (Hammond \& Axelrod, 2006). The Japanese are stereotyped as possessing a personality that lacks a fully formed ego or sense of self-sufficiency (Sugimoto, 2010). Doi claims that the concept of amae, which applies to the supposedly peculiar psychological tendency of Japanese people to achieve emotional fulfillment by winning over and relying on their superiors, is incorrect. They believe that no overt display of identity is needed. One of the most important values is community loyalty. Giving yourself to be obedient and achieve the group's aims brings a particular psychological fulfillment to the Japanese in general.

Therefore, Japanese people sometimes cannot comprehend the life or relationship of the culturally diverse culture of others. Perceptual distinctions for otherness are insufficiently detailed to allow segregation between various types of others, which might be viewed as "foreigners" or "minorities" or not at all. People perceive themselves as more "absolute" than others, even to the point where others may not appear entirely human, and the development for perceiving one's own culture is much more nuanced than those required for other cultures. As a result, people, in general, perceive themselves as more "real" than others. According to the samurai tradition, when a samurai feels humiliated by their defeat, they can destroy it with their blade, since this is the only way to die with pride.

\section{Express Group Pride}

According to experts such as Jandt and Gudykunst and Hooghe (in Zikargae, 2013), ethnocentrism is the assumption that one race is superior to another. Since ethnocentrism considers one's community to be preferable, it causes people to compare and classify other cultures by that norm (Zikargae, 2013). The following quotation reflects ethnocentrism, which leads people to believe that their society is the greatest and that they should be proud of it. 
Picture 2:

Samurai warriors practice to use their traditional sword

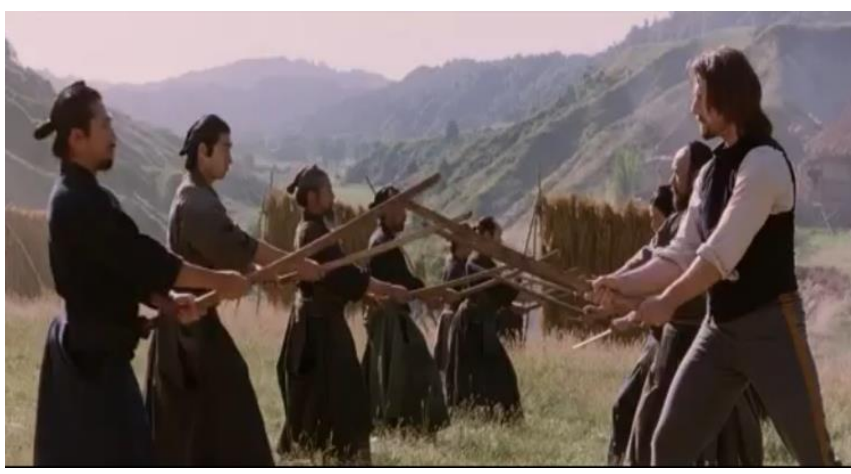

"Nathan: They are intriguing people. From the moment they wake...

... they devote themselves to the perfection of whatever they pursue."

"I have never seen such discipline. I am surprised to learn that the word "Samurai" means "to serve"..."

"... and that Katsumoto believes his rebellion to be..."

"... in the service of the Emperor." (Logan, 2003)

Although Nathan is not Japanese, he claims that the samurai community seems to be the preeminent culture. Most individuals are willing to migrate to Greek and abandon their traditions since they claim samurai customs seem to be the most dominant. He says that samurai culture is unique because it can attract him to learn about the samurai way of life. He praises the culture of samurai because Nathan never sees such a discipline in any other culture. Katsumoto as the leader of a samurai warrior believes that he is proud to serve his emperor (Neuliep et al., 2005). Neuliep further states that ethnocentric individuals communicate well with members of their groups but disagree with members of a group corroborates this. Another quotation representing the depiction of pride in samurai culture might be seen in the following. Katsumoto believes that practicing his own culture is far better than applying other cultures as follows:

"Omura: Minister Katsumoto, it is with great regret...

... but I must ask you to remove your sword."

"Katsumoto: This sword serves the Emperor. Only he can command me to remove it.

Omura: The Emperor's voice is too pure to be heard in this council."

"Katsumoto: Then, I must refuse to give up my sword" (Logan, 2003).

From Katsumoto's above statement, it can be seen that he is an ethnocentric man to his culture. He demonstrates a deep commitment to his culture and a sense of belonging toward it. And he does not want to take off or give his sword off. He resists changing the norm of samurai life to do not bring a weapon during the meeting because it is not samurai culture. On the other hand, Omura is the person who wants to change the culture of samurai. He wants to eradicate the norm by using modern culture such as western culture, but Katsumoto seems to 
resist Omura's opinion, even no one is on his side. In short, ethnocentrism is the assumption that someone's community is superior to that of another ( Kam \& Kinder, 2012). Symbols, beliefs, and rituals become an object of appreciation and pride, and in extreme circumstances hate, when viewed as belonging to out-groups, is disdain and condescending. Ethnocentrism is distinguished as an old phenomenon. However, it is a new phrase established in Sumner's ideas at the beginning of the twentieth century.

This thought is similar to McGee's and Sumner's conceptions of ethnocentrism as a group-level parallel to personal self-centeredness (Bizumic \& Duckitt, 2008). Ethnocentrism and narcissism thus have very strong and apparent connections. And ethnocentrism may and has frequently been perceived as collective narcissism. Each person is usually regarded have two kinds of person, one which concerns the distinctive qualities of the individual and the other that concerns the communities to which the individual belongs.

\section{Judge and Underestimate Out Group}

Individuals' propensity to see their ethnic community as proving the norms for appropriate attitudes and desires is known as ethnocentrism (Nurilaila et al., 2020). Ethnocentric individuals are intolerant and judgmental of civilizations other than their own. They take great pride in racial and ethnic identities of traditions, while sometimes despising the ideals of others. It can be seen from the following shot:

\section{Picture 3:}

Katsumoto judges western culture. for being too arrogant and exclusive

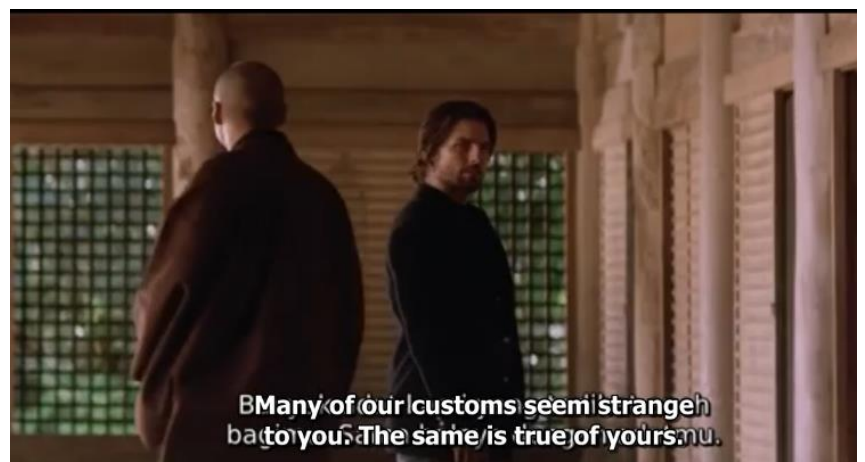

"Katsumoto: Many of our customs seem strange to you. The same is true of yours. For example... ... not to introduce yourself is considered extremely rude, even among enemies"(Logan, 2003)

The dialogues are between Katsumoto and Nathan when Nathan is curious to know about what Katsumoto wants from him. In the beginning, Katsumoto introduces himself to Nathan but Nathan does not answer it. Katsumoto wants to have a good conversation with Nathan by using English. In Japanese culture when someone meets with new people, they always bow and then introduce their name. Katsumoto sees the differences when meeting with an American soldier. He argues that enemy culture is extremely rude because he does not want to introduce himself even among enemies. 
The kind of superiority that Sumner claims might occur in several ways, according to an ethnocentric view (Etinson, 2018). Sumner's explanation evokes many kinds of hierarchies: esthetic, religious, epistemological, and moral. The view that one's groups are more ethnocentrically might therefore probably mean that it is not only fairer, but also more beautiful, devout, smart, truthful, virtuous, intriguing, or valuable than external alternative along with its beliefs, customs, norms, history, and achievements. They insert whatever positive assessment word that people truly want to perceive. However, the idea of strategic culture was less worrying to Booth (Aldrich \& Kasuku, 2012). Booth connects strategic culture and ethnocentrism to the 'group thinking' issue with their latent inclinations towards bureaucratic agreement in a classical monograph written in 1979. He states that while ethnocentrism does not lead to group thought inherently, it raises the chance of group thinking, with a drive to achieve an agreement that transcends reasonable evaluations about various ideas and actions.

Additionally, Keith says (Keith, 2015) that ethnocentrism is often misinterpreted as a synonym for general antipathy against all out-groups, suggesting a denial of ethnic plurality, widespread discrimination for out-groups, and relational selection for in-group over most out-group. According to Berry and Kalin, discrimination, xenophobia, misogyny, emotional restraint, and an oppressive personality arrangement are also behaviors associated with ethnocentrism. Ethnocentrism is characterized as in-group preferential treatment in terms of coordination and collaboration, as well as outsider-group animosity, which can contribute to intergroup conflict, aggression, or support for discriminatory acts. These are examples of how masculine manners are exercised by samurai among them in the group. In brief, ethnocentric individuals are more egotistical yet they only consider their civilization and are ignorant of other cultures. This contributes to prejudice towards other cultures, as well as judging things based on their expectations and eliminating society from other traditions from their people's existence. Whether this behavior is good or bad, Japanese people nowadays tend to behave clockwise. They tend to open themselves to global connections and start to be more overt toward global relationships. This is of course connected to global change and also caused by the spirit of accepting the otherness and opening their wide arms for diversity.

\section{CONCLUSION}

In The Last Samurai movie, the main character of Katsumoto is constructed as an ethnocentrically masculine leader. He is a leader of a samurai who has the responsibility to keep the ancestors' culture. The spirit of samurai will not be omitted from the Japanese even the foreigners try to eradicate and modernize the culture of samurai. However, ethnocentric is needed to protect people's culture from the outside's bad impact of infiltration. This has been contested when Nathan Algren, an American soldier, happens to be trapped in between the two cultures, east, and west. He has seen the contestation of completely two oppositional perspectives about Japanese culture which he has understood from the military training he joined. He changed his mind and then later on he has been falling in love with the Japanese tradition and culture, especially samurai tradition on their loyalty, self-pride, being protective toward their culture. It seems that Katsumoto's spirit and individual perseverance have touched Nathan in many ways so that he inherited Katsumoto's religious point of view about Japanese culture, which then magically turned Nathan to be the last samurai in the alienated soldiers.

Western people perceive people from other different cultures with an attitude of othering and, in this manner, the powerful groups perceive that their culture and tradition are far better and greater than other cultures. Although the samurai culture has become a famous culture, yet exploitation of weaker 
communities at the hands of more powerful social and political agents is still a burning issue. In different parts of the world, all social agents should accept and keep their culture because it is the legacy of their ancestors. This also happens in samurai culture. They protect and preserve the tradition with their very spirit of love and belonging.

Based on the analysis, this study has revealed some conclusions about ethnocentrism in Edward Zwick's The Last Samurai movie. The analysis has found out that there are three sectors of ethnocentrism revealed in the movie. First, samurai tend to have a strong relationship with others, and they are loyal to the group's norm. Second, samurai men tend to express the group's points of pride through preserving and practicing their own culture in masculine ways and these have special meanings for the group's life and bond. Third, samurai tend to underestimate the out-group because they perceive samurai culture as far better than other cultures, especially the western culture. These three aspects give effects on the development of the story dramatically because samurai people want to maintain and keep their ancestor's culture unconditionally even they do hara-kiri to show that they are deeply connected to the culture. This made Nathan Algren feels connected to the samurai culture and thus he wants to be a part of it.

Regarding the issues of east and west in the movie, The Last Samurai movie is a perfect example of how Japan, one of the Asian countries which is said to be the East as opposed to the West, develops their pride of being exclusive upon their unique culture and tradition. Japan, as has been represented by samurai, has protected their country from being the object of infiltration and injection of other countries' ideologies and beliefs. The present paper affirms that Japanese culture believes in their power and strength to protect them from the invasion of other cultures to Japan since they have developed their bumping stone for the insider and the outsider to mutually absorb each other's culture and tradition.

\section{REFERENCES}

Aldrich, R. J., \& Kasuku, J. (2012). Escaping from American intelligence : culture , ethnocentrism and the Anglosphere. 5, 1009-1028.

Bizumic, B., \& Duckitt, J. (2008). "My group is not worthy of me": Narcissism and ethnocentrism. Political Psychology, 29(3), 437-453. https://doi.org/10.1111/j.1467-9221.2008.00638.x

Etinson, A. (2018). Some Myths about Ethnocentrism. Australasian Journal of Philosophy, 96(2),

209-224. https://doi.org/10.1080/00048402.2017.1343363

Grajdian, M. (2020). Re-Framing Masculinity in Japan: Tom Cruise, The Last Samurai and the Fluid Metanarratives of History. 16(1), 50-64.

Hagakure: The Book of the Samurai - Yamamoto Tsunetomo - Google Books. (n.d.). Retrieved April 7, 2021, from https://books.google.co.id/books?hl=en\&lr=\&id=WuIImJ1kjnMC\& $\mathrm{oi}=$ fnd \&pg $=$ PR7\&dq $=$ the + last + samurai\&ots $=$ Q4bIYNhZUu\&sig $=$ Mb5hwFUH60ZIqhnRYnjZYmQJkrY\&redir_esc $=y \#_{\mathrm{v}}=$ onepage\&q\& $\mathrm{f}=$ false

Hammond, R. A., \& Axelrod, R. (2006). The evolution of ethnocentrism. Journal of Conflict Resolution, 50(6), 926-936. https://doi.org/10.1177/0022002706293470

Hooghe, M. (2008). Ethnocentrism. International Encyclopedia of the Social Sciences, 186-209. https://doi.org/10.4324/9780429275296-14 
Ingvason, P. A. D. I. (2017). Way of the Warrior in Modern Japan.

Kam, C. D., \& Kinder, D. R. (2012). Ethnocentrism as a Short-Term Force in the 2008 American Presidential Election. American Journal of Political Science, $\quad 56(2), \quad 326-340 . \quad$ https://doi.org/10.1111/j.15405907.2011.00564.x

Keith, K. D. (2015). Sumner, William G. (1840-1910). The Wiley Blackwell Encyclopedia of Race, Ethnicity, and Nationalism, 1-3. https://doi.org/10.1002/9781118663202.wberen352

Logan, J. (2003). The last samurai. In Architectural Digest (Vol. 60, Issue 11, p. 208).

Matsumoto, D. (2002). Culture, Psychology , and Education. 2, 1-15.

Neuliep, J. W., Hintz, S. M., \& McCroskey, J. C. (2005). The influence of ethnocentrism in organizational contexts: Perceptions of interviewee and managerial attractiveness, credibility, and effectiveness. Communication Quarterly, 53(1), 41-56. https://doi.org/10.1080/01463370500055954

Nurilaila, E., Ricahyono, S., Setyadi, D., \& Arifin, S. (2020). National Cultures and Politeness Strategies in Intercultural Communication Among Japanese and American Characters in "The Last Samurai" Movie: A Cross-Cultural Pragmatic Analysis. Social Sciences, Humanities and Education Journal (SHE Journal), 1(1), 10. https://doi.org/10.25273/she.v1i1.5853

Permatasari, R., Ayu, D., Sari, P., Islam, U., \& Agung, S. (2019). The Negative Effects of Ethnocentrism in My Big Fat Greek Wedding Movie. 2(0), 89-97.

Sugimoto, Y. (2010). An Introduction to Japanese Society (Third Edit). Cambridge University Press.

Sumner, G. Williams. 1906. Folkways: A Study of the Sociological Importance of Usages, Manners, Customs, Mores, and Morals. Ginn: The University of Michigan

Zikargae, M. H. (2013). "The Impacts of Ethnocentrism and Stereotype on Inter-Cultural Relations of Ethiopian Higher Education Students" in Online Journal of Communication and Media Technologies, 3(4), 126-148. 